\title{
GMR
}

\section{Canonical correlations between agronomic traits and seed physiological quality in segregating soybean populations}

E.M. Pereira, F.M. Silva, B.H.P. Val, A. Pizolato Neto, A.O. Mauro, C.C. Martins and S.H. Unêda-Trevisoli

Departamento de Produção Vegetal, Faculdade de Ciências Agrárias e Veterinárias, Universidade Estadual de São Paulo "Júlio de Mesquita Filho", Jaboticabal, SP, Brasil

Corresponding author: E.M. Pereira

E-mail: elisedematospereira@yahoo.com.br

Genet. Mol. Res. 16 (2): gmr16029547

Received November 22, 2016

Accepted February 16, 2017

Published April 13, 2017

DOI http://dx.doi.org/10.4238/gmr16029547

Copyright $(2017$ The Authors. This is an open-access article distributed under the terms of the Creative Commons Attribution ShareAlike (CC BY-SA) 4.0 License.

\begin{abstract}
The objective of this study was to evaluate the relationship between agronomic traits and physiological traits of seeds in segregating soybean populations by canonical correlation analysis. Seven populations and two commercial cultivars in three generations were used: $F_{3}$ plants and $F_{4}$ seeds; $F_{4}$ plants and $F_{5}$ seeds, and $F_{4}$ seeds and plants. The following agronomic traits (group I) were evaluated: number of days to maturity, plant height at maturity, insertion height of first pod, number of pods, grain yield, and oil content. The physiological quality of seeds (group II) was evaluated using germination, accelerated aging, emergence, and emergence rate index tests. The results showed that agronomic traits and physiological traits of seeds are not independent. Intergroup associations were established by the first canonical pair for the generation of $\mathrm{F}_{3}$ plants and $\mathrm{F}_{4}$ seeds, especially between more productive plants with a larger pod number and high oil content and seeds with a high germination percentage and emergence rate. For the generation of $F_{4}$ plants and $F_{5}$ seeds, the
\end{abstract}

Genetics and Molecular Research 16 (2): gmr16029547 
first canonical pair indicated an association between reduced maturity cycle, seeds with a high emergence percentage and a high percentage of normal seedlings after accelerated aging. According to the second canonical pair, more productive and taller plants were associated with seed vigor. For the generation of $\mathrm{F}_{4}$ seeds and plants, the associations established by the first canonical pair occurred between seed vigor and more productive plants with high oil content and reduced maturity cycle, and those established by the second canonical pair between seeds of high physiological quality and tall plants.

Key words: Multivariate analysis; Associations between traits; Glycine max; Seed quality

\section{INTRODUCTION}

Soybean cultivation plays an important role in the world's agricultural scenario and Brazil is the second largest producer (USDA, 2016). The increase in Brazilian soybean production can be attributed equally to technological advances and genetic improvement programs (Sediyama et al., 2015).

Throughout the selection process, breeders define which traits should be prioritized, while simultaneously maintaining and improving other traits (Lopes et al., 2002). In this respect, grain yield is one of the traits that are important in soybean improvement. However, it is known that traits related to seed quality are essential to obtain homogenous plant stands in the field, as well as high productivity (Mambrin et al., 2015).

Seeds are an important primary ingredient, with much of the agricultural success resulting from the use of high-quality seeds. Thus, seeds form the basis of any genetic breeding program of plants and it is through them that the technology generated is established. The selection of superior genotypes for traits related to seed quality is therefore important. A valid approach for this purpose is to determine the interrelationship between agronomic traits routinely evaluated in a breeding program and physiological traits of seeds in order to identify superior genotypes.

Knowledge of the associations that exist between traits of interest, such as those estimated by correlation analysis, is important for genetic improvement. According to Nogueira et al. (2012), correlations provide useful information that could facilitate the selection process.

The association between groups of traits can be evaluated judiciously by canonical correlation analysis. This multivariate statistical procedure permits to examine the structure of the relationship between two groups of variables, i.e., to infer the existence and intensity of the association between these variables (Hair et al., 2009).

In agronomy, canonical correlations can be established to estimate the association between two different groups of traits, for example, between physiological and agronomic traits and/or primary and secondary components of production, traits of the aerial part and root system, among others (Santos et al., 1994). Studies using canonical correlation analysis have been conducted on pigeon pea (Santos et al., 1994), beans (Coimbra et al., 2000), potato (Rigão et al., 2009), eucalyptus (Trugilho et al., 2003; Protásio et al., 2012), wheat (Carvalho et al., 2015), corn (Souza et al., 2015; Ceccon et al., 2016) and associations have been identified between groups of traits.

Genetics and Molecular Research 16 (2): gmr16029547 
Studies employing canonical correlation analysis in plants have reported promising preliminary results. However, the interrelationships between groups of traits of interest in soybean have not been investigated. Therefore, the objective of the present study was to evaluate associations between agronomic traits and traits related to seed quality in soybean.

\section{MATERIAL AND METHODS}

The field experiments for collection of the agronomic data were carried out in two agricultural years (2013/2014 and 2014/2015) in the experimental area of the Farm for Teaching, Research and Extension of Universidade Estadual Paulista "Júlio de Mesquita Filho" (UNESP-FCAV), Jaboticabal Campus, located in northern region of the State of São Paulo, Brazil (21 $14^{\prime} 5^{\prime \prime}$ South and 48 $17^{\prime} 9^{\prime \prime}$ West), at an altitude of approximately $614 \mathrm{~m}$. The soil in the experimental area is a Eutroferric Red Latosol with clayish texture. The relief is gently undulating. The climate is subtropical (Cwa) according to the classification of Köppen, with hot and humid summers and dry winters. The average annual temperature is $22.2{ }^{\circ} \mathrm{C}$.

Seven populations of the $\mathrm{F}_{3}$ and $\mathrm{F}_{4}$ generation, derived from biparental crosses of soybean parental lines differing in oil content, as well as two commercial cultivars (MG/BR 46 Conquista and Coodetec 216), were studied.

The augmented block design proposed by Federer (1956) was used, with 120 offspring in the $\mathrm{F}_{3}$ generation and 83 in the $\mathrm{F}_{4}$ generation. Each plot consisted of 5-m long rows spaced $0.5 \mathrm{~m}$ apart. The data were collected from six individual plants selected within each plot. The following agronomic traits were evaluated: number of days to maturity (NDM), insertion height of first pod (IHP), plant height at maturity (PHM), number of pods per plant (NP), and grain yield (GY) expressed in gram per plant. In addition, the oil content (OC) of the seeds was determined without destroying the seeds by near-infrared spectroscopy in a TANGO spectrometer (Bruker).

Seed physiological quality of the genotypes was evaluated after bulk harvest of the plants within the experimental plots by germination and vigor tests. The germination test was performed according to the Regras de Análises de Sementes (Brasil, 2009). It was prepared on rolls of paper towels (Germitest), which had been previously moistened with distilled water in the proportion of 2.5 times the initial weight. They were then placed into germinators, the count of the seedlings classified as normal was made 5 and 8 days after sowing, and the results are reported as a percentage.

For the evaluation of seedling emergence, four replicates of 50 seeds distributed in plastic trays covered with sand were used. After sowing, the trays were kept in a plant growth room at $25^{\circ} \mathrm{C}$ under a 12-h photoperiod. Emerging seedlings were counted daily until stabilization of the stand. The percentage of normal seedlings after 9 days and the emergence rate index (ERI) determined as proposed by Maguire (1962) were considered for analysis.

The accelerated aging test was performed using an adaptation of the gerbox method. In each gerbox containing $40 \mathrm{~mL}$ distilled water, 200 seeds were placed in a single layer on a suspended screen. The boxes were maintained in a BOD incubator at $42^{\circ} \mathrm{C}$ for $48 \mathrm{~h}$. After this period, the seeds were allowed to germinate as described for the germination test (Marcos Filho, 1999). The count of the seedlings classified as normal was made 5 days after sowing and the results are reported as a percentage.

Seed quality was analyzed in a randomized block design with four replicates of 50 seeds. The canonical groups were established from the agronomic traits (group I) and seed

Genetics and Molecular Research 16 (2): gmr16029547 
physiological traits (group II) to verify associations between these traits in the generations. Group I comprised NDM, IHP, PHM, NP, GY, and OC, while group II consisted of germination percentage $(\mathrm{G})$, emergence percentage (E), ERI, and accelerated aging (AA). Thus, four canonical functions could be determined.

Prior to canonical correlation analysis, Pearson's linear correlations (within group I, within group II, and between groups) were estimated for each generation to evaluate the existence of multicollinearity within each group and the linearity between traits (Rigão et al., 2009; Protásio et al., 2012). Significance was verified by the $t$-test.

The canonical correlations were estimated for the following generations: $F_{3}$ plants and $\mathrm{F}_{4}$ seeds, $\mathrm{F}_{4}$ plants and $\mathrm{F}_{5}$ seeds, and $\mathrm{F}_{4}$ seeds and plants. The analyses were performed using the Statistica 10 software (StatSoft, Inc., 2010). A level of significance of $\mathrm{P}<0.05$ was established for selection of the canonical functions. The canonical loading value that defines the variables to be analyzed in each function was set at $>0.05$.

\section{RESULTS AND DISCUSSION}

Analysis of the linear correlations between traits of group I (NDM, IHP, PHM, NP, GY, and OC) and group II (G, E, ERI, and AA) revealed 18 significant correlations in which all traits related to seed quality were positively correlated with each other and with oil content in the generation of $\mathrm{F}_{3}$ plants and $\mathrm{F}_{4}$ seeds (Table 1).

Table 1. Correlations between plant agronomic traits (group I) and seed physiological traits (group II) of soybean analyzed on generation with plants $\mathrm{F}_{3}$ and seeds $\mathrm{F}_{4}$.

\begin{tabular}{l|c|c|c|c|c|c|c|c|c}
\hline & ERI & E & AA & NDM & IHP & PHM & NP & GY & OC \\
\hline G & $0.786^{* *}$ & $0.865^{* *}$ & $0.749^{* *}$ & $-0.306^{\text {ns }}$ & $0.008^{\text {ns }}$ & $-0.190^{\text {ns }}$ & $-0.232^{\text {ns }}$ & $-0.166^{\text {ns }}$ & $0.616^{* *}$ \\
\hline ERI & - & $0.790^{* *}$ & $0.734^{* *}$ & $-0.257^{\text {ns }}$ & $-0.007^{\text {ns }}$ & $-0.167^{\text {ns }}$ & $0.354^{*}$ & $-0.237^{\text {ns }}$ & $0.346^{*}$ \\
\hline E & & - & $0.690^{* *}$ & $-0.266^{\text {ns }}$ & $-0.115^{\text {ns }}$ & $-0.194^{\text {ns }}$ & $-0.209^{\text {ns }}$ & $-0.173^{\text {ns }}$ & $0.524^{* *}$ \\
\hline AA & & & - & $-0.456^{*}$ & $0.021^{\text {ns }}$ & $0.056^{\text {ns }}$ & $-0.235^{\text {ns }}$ & $-0.114^{\text {ns }}$ & $0.513^{* *}$ \\
\hline NDM & & & & - & $-0.065^{\text {ns }}$ & $-0.014^{\text {ns }}$ & $0.321^{*}$ & $0.221^{\text {ns }}$ & $-0.534^{* *}$ \\
\hline IHP & & & & & - & $0.305^{\text {ns }}$ & $0.346^{*}$ & $0.340^{*}$ & $-0.145^{\text {ns }}$ \\
\hline PHM & & & & & & - & $-0.047^{\text {ns }}$ & $-0.004^{\text {ns }}$ & $0.028^{\text {ns }}$ \\
\hline NP & & & & & & & - & $0.912^{* *}$ & $0.347^{*}$ \\
\hline GY & & & & & & & & - & $0.240^{\text {ns }}$ \\
\hline
\end{tabular}

Group I: NDM, number of days to maturity; IHP, insertion height of first pod; PHM, plant height at maturity; NP, number of pods per plant; GY, grain yield; OC, oil content. Group II: G, germination percentage; ERI, emergence rate index; E, emergence percentage; $\mathrm{AA}$, accelerated aging. ${ }^{*}$ Significant at $1 \%$, * significant at $5 \%$, and ${ }^{\mathrm{ns}}$ not significant at $5 \%$.

A positive correlation coefficient indicates that as one variable increases the other variable increases, or as one decreases the other decreases, whereas as a negative correlation indicates that as one variable increases, the other decreases or vice-versa (Nogueira et al., 2012).

The positive and highly significant correlation between these seed traits was somehow expected since, although different aspects of seed physiological quality were evaluated, the experiment was conducted simultaneously using the same samples.

The significant and high correlations between the seed quality traits evaluated in this study corroborate the findings of Schuab et al. (2008) who investigated the physiological potential of seeds of soybean genotypes.

The physiological processes of germination and vigor are influenced by protein, lipid, starch, and sugar content. In this respect, an increase in oil content and total carbohydrates may

Genetics and Molecular Research 16 (2): gmr16029547 
positively influence the germination and vigor of seedlings by providing soluble carbohydrates that can be absorbed by the embryo (Moraes et al., 2006).

Significant negative correlations at the $5 \%$ probability level were observed between NDM and accelerated aging (Table 1). The reduction in NDM exerted an influence by increasing the percentage of normal seedlings after stress. The accelerated aging test uses environmental factors that are commonly associated with seed deterioration.

Several studies have reported a loss of seed quality when the seeds are exposed to adverse conditions of relative humidity and temperature during the process of maturation and after the point of physiological maturity. In this respect, under the conditions encountered in Brazil where high temperature and excessive rainfall predominate during soybean maturation, precocity should be highlighted as an escape mechanism in response to adverse environmental conditions (Trzeciak, 2012).

The correlations between number of pods, NDM, IHP, OC, and ERI were significant and positive (Table 1). Grain yield was correlated with IHP and highly correlated with the number of pods. Soybean plants with a larger number of pods are directly responsible for increased productivity (Souza et al., 2013) in such a way that this trait can be used to indirectly select for soybean productivity (Nogueira et al., 2012; Sousa et al., 2015).

Multicollinearity was verified by the condition number of the matrix in the two groups (agronomic traits and physiological traits of seeds) and was found to be weak (condition number $=43.95$ ). This fact permitted the use of all traits in the canonical correlation analyses (Toebe and Cargnelutti Filho, 2013) since, when variables are correlated, the effect of collinearity may lead to poorly reliable results and misleading conclusions in this analysis (Cruz et al., 2014).

The canonical correlations between the agronomic traits and seed physiological traits were significant $(\mathrm{P}<0.01$, chi-squared test $)$ only in the first canonical pair. This pair was therefore of interest to the study. As can be seen in Table 2, the total correlation for this pair was high $(\mathrm{r}=0.7183)$.

Table 2. Canonical loads of plant agronomic traits (group I) and seed physiological traits (group II) of soybean on canonical correlations $(r)$ between the groups on generation with plants $\mathrm{F}_{3}$ and seeds $\mathrm{F}_{4}$.

\begin{tabular}{|c|c|c|c|c|c|}
\hline \multirow{2}{*}{ Groups } & \multicolumn{5}{|c|}{ Canonical pairs } \\
\hline & Characters & $1^{\circ}$ & $2^{\circ}$ & $3^{\circ}$ & $4^{\circ}$ \\
\hline \multirow[t]{6}{*}{ I } & NDM & 0.0657 & -0.4258 & 0.5133 & 0.7066 \\
\hline & IHP & -0.0463 & 0.4747 & 0.1614 & 0.9709 \\
\hline & PHM & -0.1782 & 0.4061 & -0.6537 & 0.3301 \\
\hline & NP & 0.8403 & -1.5160 & -1.3675 & 0.1645 \\
\hline & GY & 0.5544 & 1.1802 & 0.6422 & -0.1973 \\
\hline & $\mathrm{OC}$ & 1.0951 & -0.0540 & 0.0813 & 0.4011 \\
\hline \multirow[t]{6}{*}{ II } & $\mathrm{G}$ & 1.1046 & 0.0105 & 0.6354 & 1.8368 \\
\hline & ERI & 1.0450 & 0.5300 & 1.3869 & -0.2736 \\
\hline & $\mathrm{E}$ & 0.4940 & -1.0813 & -0.4977 & -1.6997 \\
\hline & AA & 0.1381 & 1.1161 & -1.1052 & -0.3471 \\
\hline & $\mathrm{r}$ & 0.7183 & 0.5475 & 0.4915 & 0.2720 \\
\hline & $\rho$ & $0.0025^{* *}$ & $0.0690^{\mathrm{ns}}$ & $0.1586^{\mathrm{ns}}$ & $0.4619^{\mathrm{ns}}$ \\
\hline
\end{tabular}

Group I: NDM, number of days to maturity; IHP, insertion height of first pod; PHM, plant height at maturity; NP, number of pods per plant; GY, grain yield; OC, oil content. Group II: G, germination percentage; ERI, emergence rate index; E, emergence percentage; AA, accelerated aging. ${ }^{*}$ Significant at $1 \%$ and ${ }^{\mathrm{ns}}$ not significant at $1 \%$.

The higher the canonical loading, the more important is the variable to derive the canonical variate (Hair et al., 2009). Analysis of the canonical loadings for the canonical variate related to the agronomic traits showed high values for number of pods, grain yield,

Genetics and Molecular Research 16 (2): gmr16029547 
and oil content (Table 2). These variables can be considered the most important in this group (Protásio et al., 2014). Regarding the traits related to seed quality, the canonical loadings were high for germination and ERI (Table 2), with these traits contributing to the canonical variates. Thus, the coefficient of the first canonical pair permitted to establish intergroup associations. The relationship between more productive plants, a larger number of pods and high oil content is determinant for the increase in germination percentage and seed emergence rate measured by the ERI. In most cases, plants with high performance produce a larger number of pods and seeds, increasing productivity (Souza et al., 2013), and a high oil content is correlated with high productivity (Farias Neto and Vello, 2001).

Good performance of soybean crops depends fundamentally on the germination and vigor of the seeds. In this respect, the use of seed lots of high physiological quality provides an average gain of $39 \%$ in productivity (Andreoli et al., 2002), a fact explaining the great influence of these variables.

Sixteen significant correlations were observed in the generation of $F_{4}$ plants and $F_{5}$ seeds (Table 3 ), in which all traits related to seed quality were positively correlated with each other. In addition, these traits were correlated with PHM, i.e., plants derived from high-quality seeds have a greater height (Schuch et al., 2009).

Table 3. Correlations between plant agronomic traits (group I) and seed physiological traits (group II) of soybean analyzed on generation with plants $\mathrm{F}_{4}$ and seeds $\mathrm{F}_{5}$.

\begin{tabular}{l|c|c|c|c|c|c|c|c|c}
\hline & ERI & E & AA & NDM & IHP & PHM & NP & GY & OC \\
\hline G & $0.777^{* *}$ & $0.756^{* *}$ & $0.498^{* *}$ & $-0.189^{\text {ns }}$ & $-0.002^{\text {ns }}$ & $0.475^{* *}$ & $-0.271^{\text {ns }}$ & $0.144^{\text {ns }}$ & $0.144^{\text {ns }}$ \\
\hline ERI & - & $0.938^{* *}$ & $0.499^{* *}$ & $-0.205^{\text {ns }}$ & $-0.143^{\text {ns }}$ & $0.537^{* *}$ & $-0.335^{\text {ns }}$ & $0.069^{\text {ns }}$ & $0.271^{\text {ns }}$ \\
\hline E & & - & $0.537^{* *}$ & $-0.231^{\text {ns }}$ & $-0.172^{\text {ns }}$ & $0.609^{* *}$ & $-0.343^{\text {ns }}$ & $0.083^{\text {ns }}$ & $0.253^{\text {ns }}$ \\
\hline AA & & & - & $-0.554^{* *}$ & $0.147^{\text {ns }}$ & $0.489^{* *}$ & $-0.274^{\text {ns }}$ & $-0.113^{\text {ns }}$ & $0.420^{*}$ \\
\hline NDM & & & & - & $0.267^{\text {ns }}$ & $0.044^{\text {ns }}$ & $-0.176^{\text {ns }}$ & $-0.325^{*}$ & $0.384^{*}$ \\
\hline IHP & & & & & - & $0.103^{\text {ns }}$ & $0.017^{7^{n s}}$ & $-0.113^{\text {ns }}$ & $-0.140^{\text {ns }}$ \\
\hline PHM & & & & & & - & $0.302^{\text {ns }}$ & $0.284^{\text {ns }}$ & $-0.095^{\text {ns }}$ \\
\hline NP & & & & & & & - & $0.649^{* *}$ & $0.376^{*}$ \\
\hline GY & & & & & & & & - & $0.260^{\text {ns }}$ \\
\hline
\end{tabular}

Group I: NDM, number of days to maturity; IHP, insertion height of first pod; PHM, plant height at maturity; NP, number of pods per plant; GY, grain yield; OC, oil content. Group II: G, germination percentage; ERI, emergence rate index; E, emergence percentage; AA, accelerated aging. $* *$ Significant at $1 \%$, *significant at $5 \%$ and ${ }^{\mathrm{ns}}$ not significant at $5 \%$.

There was a significant negative correlation between NDM and accelerated aging, demonstrating that an increase in life cycle tends to reduce seed vigor evaluated by the accelerated aging test.

With respect to grain yield, this trait was positively correlated with the number of pods (Table 3). Grain yield is one of the most important components of soybean productivity since alterations in these components are directly responsible for productivity (Dalchiavon and Carvalho, 2012).

The correlations between grain yield and NDM were significant and negative. Similar results have been reported by Bisinotto (2014) who studied the correlation between agronomic traits of soybean genotypes. Salimi and Moradi (2012) found that the correlation of these traits follows the same pattern under conditions of water stress.

Oil content was positively correlated with accelerated aging, NDM, and the number of pods (Table 3 ). 
Analysis of multicollinearity in the groups of agronomic and seed physiological traits showed weak multicollinearity, with a condition number of 77.66.

In the generation of $\mathrm{F}_{4}$ plants and $\mathrm{F}_{5}$ seeds, the canonical pairs 1 and 2 were found to be significant at the $1 \%$ level of probability, demonstrating the dependence between traits (Table 4). Consequently, the first two canonical pairs are of interest to the study since these pairs maximize the relationship between agronomic and seed physiological traits in soybean.

Table 4. Canonical loads of plant agronomic traits (group I) and seed physiological traits (group II) of soybean on canonical correlations ( $\mathrm{r}$ ) between the groups on generation with plants $\mathrm{F}_{4}$ and seeds $\mathrm{F}_{5}$.

\begin{tabular}{|c|c|c|c|c|c|}
\hline \multirow[t]{2}{*}{ Groups } & \multicolumn{5}{|c|}{ Canonical pairs } \\
\hline & Characters & $1^{\circ}$ & $2^{\circ}$ & $3^{\circ}$ & $4^{\circ}$ \\
\hline \multirow[t]{6}{*}{ I } & NDM & -0.9449 & 0.3030 & -0.0799 & 0.4617 \\
\hline & IHP & -0.0588 & -0.0639 & -0.7579 & -0.5122 \\
\hline & PHM & -0.0532 & 0.8164 & -0.0760 & -0.5712 \\
\hline & NP & -0.3320 & -0.4796 & 0.5510 & 0.3215 \\
\hline & GY & 0.1948 & 0.6895 & -0.7825 & -0.0400 \\
\hline & $\mathrm{OC}$ & 0.0278 & 0.2474 & 0.3764 & -0.9037 \\
\hline \multirow[t]{6}{*}{ II } & $\mathrm{G}$ & 0.3519 & 0.0503 & -1.5871 & 0.0731 \\
\hline & ERI & 0.3416 & 0.1802 & 0.7474 & -2.9168 \\
\hline & $E$ & 1.0832 & 0.7135 & 0.6215 & 2.6038 \\
\hline & AA & 1.0710 & 0.5526 & 0.0029 & 0.0032 \\
\hline & $\mathrm{r}$ & 0.8771 & 0.8221 & 0.2889 & 0.1686 \\
\hline & $\rho$ & $0.0000 * *$ & $0.0003^{* *}$ & $0.8673^{\text {ns }}$ & $0.8095^{\text {ns }}$ \\
\hline
\end{tabular}

Group I: NDM, number of days to maturity; IHP, insertion height of first pod; PHM, plant height at maturity; NP, number of pods per plant; GY, grain yield; OC, oil content. Group II: G, germination percentage; ERI, emergence rate index; E, emergence percentage; AA, accelerated aging. ** Significant at $1 \%$ and ${ }^{\text {ns }}$ not significant at $1 \%$.

The canonical coefficients clearly indicate the relationship between traits in which NDM exhibited a higher relative canonical (module) loading in group I and emergence and accelerated aging in group II (Table 4).

The intergroup associations established by the first pair of canonical correlations associated a short cycle with a high emergence percentage and a high percentage of normal seedlings under conditions of accelerated aging (Table 4). In the second pair of canonical correlations, PHM and GY exhibited higher values in group I, while the traits contributing most in group II were the same as those associated by the first canonical pair (Table 4).

These results associate highly productive and tall plants with seeds exhibiting a greater capacity of emergence and tolerance to stress caused by accelerated aging, i.e., with high vigor. A study evaluating the effect of seed vigor on soybean productivity showed that seeds with high vigor provided greater grain yield and the plants derived from these seed lots were taller up to 75 days after sowing (Scheeren et al., 2010). The selection of more productive soybean plants usually results in a correlated response of taller plants (Oliveira, 2008). The statistical significance observed for the first two canonical pairs indicates the existence of a relationship between agronomic and seed physiological traits in soybean.

The linear correlations between traits of group II (G, ERI, E, and AA) were significant and high for the generation of $\mathrm{F}_{4}$ seeds and $\mathrm{F}_{4}$ plants (Table 5). Martins et al. (2016), evaluating the correlations between seed traits to identify tests that could select soybean lines with seeds of high germination, vigor, and field performance, observed highly significant correlations ranging from 0.59 to $0.99 \%$ between the traits studied.

Genetics and Molecular Research 16 (2): gmr16029547 
Table 5. Correlations between plant agronomic traits (group I) and seed physiological traits (group II) of soybean analyzed on generation with plants $\mathrm{F}_{4}$ and seeds $\mathrm{F}_{4}$.

\begin{tabular}{l|c|c|c|c|c|c|c|c|c}
\hline & ERI & E & AA & NDM & IHP & PHM & NP & GY & OC \\
\hline G & $0.786^{* *}$ & $0.865^{* *}$ & $0.749^{* *}$ & $-0.448^{* *}$ & $0.369^{*}$ & $-0.277^{\text {ns }}$ & $-0.122^{\text {ns }}$ & $0.345^{* *}$ & $0.245^{\text {ns }}$ \\
\hline ERI & - & $0.790^{* *}$ & $0.734^{* *}$ & $-0.458^{* *}$ & $0.410^{* *}$ & $0.060^{\text {ns }}$ & $0.032^{\text {ns }}$ & $0.469^{* *}$ & $0.017^{\text {ns }}$ \\
\hline E & & - & $0.690^{* *}$ & $-0.498^{* *}$ & $0.354^{*}$ & $-0.153^{\text {ns }}$ & $-0.11^{\text {ns }}$ & $0.303^{*}$ & $-0.07^{\text {ns }}$ \\
\hline AA & & & - & $-0.589^{* *}$ & $0.462^{* *}$ & $0.066^{\text {ns }}$ & $-0.054^{\text {ns }}$ & $0.363^{*}$ & $0.159^{\text {ns }}$ \\
\hline NDM & & & & - & $0.267^{\text {ns }}$ & $0.044^{\text {ns }}$ & $-0.176^{\text {ns }}$ & $-0.325^{*}$ & $0.384^{*}$ \\
\hline IHP & & & & & - & $-0.103^{\text {ns }}$ & $0.017^{\text {ns }}$ & $-0.113^{\text {ns }}$ & $-0.140^{\text {ns }}$ \\
\hline PHM & & & & & & - & $0.302^{\text {ns }}$ & $0.284^{\text {ns }}$ & $-0.095^{\text {ns }}$ \\
\hline NP & & & & & & & - & $0.649^{* *}$ & $0.376^{*}$ \\
\hline GY & & & & & & & & - & $0.260^{\text {ns }}$ \\
\hline
\end{tabular}

Group I: NDM, number of days to maturity; IHP, insertion height of first pod; PHM, plant height at maturity; NP, number of pods per plant; GY, grain yield; OC, oil content. Group II: G, germination percentage; ERI, emergence rate index; E, emergence percentage; AA, accelerated aging. ${ }^{* *}$ Significant at $1 \%$, *significant at $5 \%$ and ${ }^{\mathrm{ns}}$ not significant at $5 \%$.

A significant positive correlation was also observed for seed physiological traits with IHP and grain yield (Table 5). However, the vigor levels of the seed lots did not affect the IHP of the plants in the study of Rossi (2012). A close relationship between seed vigor and productivity has been reported, in which high-vigor seeds resulted in an increase of 20 to $35 \%$ in grain yield compared to low-vigor seeds (França-Neto et al., 2014).

On the other hand, the seed traits showed a significant and inverse correlation with NDM (Table 5). Low-vigor seed lots have been shown to prolong the vegetative phase of plants (Vanzolini and Carvalho, 2002), which is intimately related to the reproductive cycle of a genotype.

The condition number (Cruz et al., 2014) found was 146.8, indicating relatively weak multicollinearity. Thus, all variables studied were maintained for canonical correlation analysis.

The canonical correlations between groups were significant by the chi-squared test at the 1\% level $(\mathrm{P}<0.01)$ for the first canonical pair. The total correlation of this canonical pair was high $(\mathrm{r}=0.8573)$. The second canonical pair was significant by the chi-squared test at the $5 \%$ level $(\mathrm{P}<0.05$; Table 6$)$.

Table 6. Canonical loads of plant agronomic traits (group I) and seed physiological traits (group II) of soybean on canonical correlations ( $\mathrm{r}$ ) between the groups on generation with plants $\mathrm{F}_{4}$ and seeds $\mathrm{F}_{4}$.

\begin{tabular}{|c|c|c|c|c|c|}
\hline \multirow[t]{2}{*}{ Groups } & \multicolumn{5}{|c|}{ Canonical pairs } \\
\hline & Characters & $1^{\circ}$ & $2^{\circ}$ & $3^{\circ}$ & $4^{\circ}$ \\
\hline \multirow[t]{6}{*}{ I } & NDM & -0.5998 & -0.3234 & -0.1707 & 0.8118 \\
\hline & IHP & -0.1931 & -0.2152 & 0.1960 & -0.2173 \\
\hline & PHM & -0.1918 & 0.7972 & 0.5720 & -0.0862 \\
\hline & NP & -0.3663 & -0.2316 & 0.6193 & -0.0872 \\
\hline & GY & 0.6493 & -0.0539 & -0.3606 & 0.9988 \\
\hline & $\mathrm{OC}$ & 0.5674 & -0.4505 & 0.9182 & -0.2288 \\
\hline \multirow[t]{6}{*}{ II } & $\mathrm{G}$ & 0.8837 & 1.9818 & 0.4170 & 0.3398 \\
\hline & ERI & 0.0430 & 0.6917 & 0.1517 & 1.6935 \\
\hline & $\mathrm{E}$ & 0.3542 & 0.7857 & -1.7023 & -0.9536 \\
\hline & AA & 0.5184 & 0.8291 & 0.8255 & -0.9845 \\
\hline & $\mathrm{r}$ & 0.8573 & 0.6698 & 0.3919 & 0.3593 \\
\hline & $\rho$ & $0.0000^{* * *}$ & $0.0114^{*}$ & $0.2503^{\mathrm{ns}}$ & $0.2009^{\mathrm{ns}}$ \\
\hline
\end{tabular}

Group I: NDM, number of days to maturity; IHP, insertion height of first pod; PHM, plant height at maturity; NP, number of pods per plant; GY, grain yield; OC, oil content. Group II: G, germination percentage; ERI, emergence rate index; E, emergence percentage; AA, accelerated aging. ${ }^{*}$ Significant at $1 \%$, ${ }^{*}$ significant at $5 \%$ and ${ }^{\mathrm{ns}}$ not significant at $5 \%$.

Genetics and Molecular Research 16 (2): gmr16029547 
According to the canonical loadings of the first pair regarding group I, it was observed that NDM, GY, and OC showed high values (in module). For group II, germination and accelerated aging exhibited high canonical loadings (Table 6).

The relationships expressed by the first canonical pair indicate that seeds with high germination and vigor potential are associated with more productive plants with a high oil content and reduced cycle. These results suggest that high-quality seeds originate more productive plants. It is known that high-vigor seeds provide fast and uniform germination and emergence, originating high-performance plants with a great production potential (FrançaNeto et al., 2014).

In the second canonical pair, high loading was only observed for PHM in group I, while in group II all variables exhibited loadings higher than 0.5 (Table 6).

The results demonstrated by the second canonical pair indicated that high-quality seeds are associated with tall plants. For rice crops, Höfs et al. (2004) showed that seeds of higher physiological quality produce larger seedlings that result in higher growth rates.

It can be inferred that the degree of association between traits varies from one generation to the other. This fact highlights the need to estimate canonical correlations within each generation of the population under improvement to increase the efficiency of selection.

In view of the lack of studies using canonical correlation analysis for soybean crops, further investigations applying this analysis to different genotypes and generations are needed to better understand the relationship between the traits studied here and to support the results and observations highlighted in the present study.

\section{CONCLUSIONS}

Canonical correlation analysis permitted to efficiently draw inferences about agronomic traits and seed quality of soybean. The agronomic and seed physiological traits are not independent. More productive plants with a larger number of pods and high oil content are associated with seeds with a high germination percentage and emergence rate. Plants with a reduced maturity cycle are associated with seeds that exhibit a high emergence percentage and are more tolerant to conditions of accelerated aging. In addition, more productive and taller plants are associated with greater seed vigor. Seeds with a high germination percentage and vigor are associated with more productive plants with high oil content and reduced maturity cycle. An association exists between high-quality seeds and tall plants.

\section{ACKNOWLEDGMENTS}

The authors thank Fundação de Amparo à Pesquisa do Estado de São Paulo (Project \#2011/12958-9) for financial support and scholarships, and Coordenação de Aperfeiçoamento de Pessoal de Nível Superior for doctorate and sandwich doctorate scholarships.

\section{REFERENCES}

Andreoli C, Andrade RV, Zamora SA and Gordon M (2002). The effect of seed germination and seeding rate on corn standest ablishment and yield. Rev. Bras. Sementes 24: 1-5. http://dx.doi.org/10.1590/S0101-31222002000200001

Bisinotto FF (2014). Correlações entre caracteres como critério de seleção indireta, adaptabilidade e estabilidade em genótipos de soja. Dissertação (Mestrado em Agronomia). Universidade Federal de Uberlândia, Uberlândia. Available at [https://repositorio.ufu.br/handle/123456789/12201].

Genetics and Molecular Research 16 (2): gmr16029547 
Brasil (2009). Regras para análise de sementes. Ministério da Agricultura, Pecuária e Abastecimento, MAPA/ACS, Brasília.

Carvalho IR, de Souza VQ, Nardino M, Follmann DN, et al. (2015). Canonical correlations between morphological traits and yield components in dual purpose. Pesqui. Agropecu. Bras. 50: 690-697. http://dx.doi.org/10.1590/S0100204X2015000800007

Ceccon G, dos Santos A, Teodoro PE and da Silva CA, Junior. (2016). Relationships between Primary and Secondary Yield Components of a Maize Population after 13 Stratified Mass Selection Cycles. J. Agron. 15: 33-38. http://dx.doi. org/10.3923/ja.2016.33.38

Coimbra JLM, Guidolin AF, de Carvalho FIF and de Azevedo R (2000). Canonical correlations: II - analysis of bean yield and yield components. Cienc. Rural 30: 31-35. http://dx.doi.org/10.1590/S0103-84782000000100005

Cruz CD, Regazzi AJ and Carneiro PCS (2014). Modelos biométricos aplicados ao melhoramento genético. $3^{\mathrm{a}}$ ed. Universidade Federal de Viçosa, Viçosa.

Dalchiavon FC and Carvalho MP (2012). Linear and spatial correlation of the yield components and soybean yield. Semin. Cienc. Agrar. 33: 541-552 http://dx.doi.org/10.5433/1679-0359.2012v33n2p541.

Farias Neto JT and Vello NA (2001). Evaluation of F4:3 and F5:3 progenies and estimation of genetic parameters with emphasys to oil percentage and grain and oil yield of soybean. Cienc. Agrotec. 25: 812-820.

Federer WT (1956). Augmented (hoonuiaku) designs. Hawaii. Planters Rec. 55: 191-208.

França-Neto JB, Krzyzanowski FC, Henning AA, Lorini I, et al. (2014). A relação de alto vigor e a produtividade. Granja 789: 34-37.

Hair JF, Black W, Babin B, Anderson RE, et al. (2009). Análise Multivariada de dados. $6^{\mathrm{a}}$ ed. Editora Bookman, Porto Alegre.

Höfs A, Schuch LOB, Peske ST and Barros ACSA (2004). Emergence and initial growth of rice seedlings according to seed vigor. Rev. Bras. Sementes 26: 92-97.

Lopes JC, Martins-Filho S, Tagliaferre C and Rangel OJP (2002). Physiological seed quality evaluation of soybean produced in Alegre, Espírito Santo State. Rev. Bras. Sementes 23: 201-208.

Maguire JD (1962). Speed of germination aid in selection and evaluation for seedling emergence and vigor. Crop Sci. 2: 176-177. http://dx.doi.org/10.2135/cropsci1962.0011183X000200020033x

Mambrin RB, Ribeiro ND, Henning LMM, Henning FA, et al. (2015). Selection of common bean lines for standard and quality seeds. Rev. Caatinga 28: 147-156. http://dx.doi.org/10.1590/1983-21252015v28n317rc

Marcos Filho J (1999). Teste de envelhecimento acelerado. In: Vigor de sementes: conceitos e testes (Krzyzanowski FC, et al., eds.). Abrates, Londrina.

Martins CC, Unêda-Trevisoli SH, Môro GV and Vieira RD (2016). Methodology for the selection of soybean strains for germination, vigour and field emergence. Rev. Cienc. Agron. 47: 455-461. http://dx.doi.org/10.5935/1806$\underline{6690.20160055}$

Moraes RMA, José IC, Ramos FG, de Barros EG, et al. (2006). Biochemical characterization of high protein soybean lines. Pesqui. Agropecu. Bras. 41: 725-729 10.1590/S0100-204X2006000500002.

Nogueira APO, Sediyama T, de Sousa LB, Hamawaki OT, et al. (2012). Path analysis and correlations among traits in soybean grown in two dates sowing. Biosci. J. 28: 877-888.

Oliveira M (2008). Temperatura na secagem e condições de armazenamento sobre propriedades da soja para consumo e produção de biodiesel. Dissertação (Mestrado em Ciência e Tecnologia Agroindustrial). Universidade Federal de Pelotas, Pelotas. Available at [http://repositorio.ufpel.edu.br:8080/handle/123456789/1314].

Protásio TDP, Neto G, Maciel R, Santana JDDPD, et al. (2014). Canonical correlation analysis of the characteristics of charcoal from Qualea parviflora Mart. Cerne 20: 81-88. http://dx.doi.org/10.1590/S0104-77602014000100011

Protásio TP, Tonoli GHD, Júnior MG, Bufalino L, et al. (2012). Canonical correlations between chemical and energetic characteristics of lignocellulosic wastes. Cerne 18: 433-439.

Rigão MH, Storck L, Bisognin DA and Lopes SJ (2009). Canonical correlation for tuber trait to assist early selection of potato clones. Cienc. Rural 39: 2347-2353.

Rossi RF (2012). Vigor de sementes, população de plantas e desempenho agronômico de soja. Dissertação (Mestrado em Agronomia). Faculdade de Ciências Agronômicas Câmpus de Botucatu, Universidade Estadual Paulista "Júlio de Mesquita Filho", Botucatu. Available at [http://repositorio.unesp.br/handle/11449/86387].

Salimi S and Moradi S (2012). Effect the correlation, regression and path analysis in soybean genotypes (Glycine max L.) under moisture and normal condition. Int. J. Agron. Plant Prod 3: 447-454.

Santos CAF, Cavalcanti J, Paini JN and Cruz CD (1994). Canonical correlations between primary and secondary componentes in the grains of pigeon pea (Cajanus cajan (L.) Millsp). Ceres 41: 469-464.

Scheeren BR, Peske ST, Schuch LOB and Barros ACA (2010). Physiological quality of soybean seeds and productivity.

Genetics and Molecular Research 16 (2): gmr16029547 
Rev. Bras. Sementes 32: 35-41. http://dx.doi.org/10.1590/S0101-31222010000300004

Schuab SRP, de Lucca A, Neto JDBF, Scapim CA, et al. (2008). Soybean physiological seed potential and the relationship with seedlings emergence in field. Acta Sci. Agron. 28: 553-561.

Schuch LOB, Kolchinski EM and Finatto JA (2009). Seed physiological quality and individual plants performance in soybean. Rev. Bras. Sementes 31: 144-149. http://dx.doi.org/10.1590/S0101-31222009000100016

Sediyama T, Teixeira RC and Barros HB (2015). Origem, Evolução e importância econômica. In: Tecnologias de produção e usos da soja (Sediyama T, eds.). Mecenas, Londrina.

Sousa LB, Júnior CDS, Romanato FN, Hamawaki OT, et al. (2015). Correlation between yield components in F6 soybean progenies derived from seven biparental crosses. Biosci. J. 31: 1692-1699. http://dx.doi.org/10.14393/BJv31n6a2015-26217

Souza CA, Figueiredo BP, Coelho CMM, Casa RT, et al. (2013). Plant architecture and productivity of soybean affected by plant growth retardants. Biosci. J. 29: 634-643.

Souza VQ, Baretta D, Nardino M, Carvalho IR, et al. (2015). Variance components and association between corn hybrids morpho-agronomic characters. Cientifica 43: 246-253. http://dx.doi.org/10.15361/1984-5529.2015v43n3p246-253

StatSoft, Inc. (2010). STATISTICA, versão 10. Available at [www.statsoft.com].

Toebe M and Cargnelutti Filho A (2013). Multivariate nonnormality and multicollinearity in path analysis in corn. Pesqui. Agropecu. Bras. 48: 466-477. http://dx.doi.org/10.1590/S0100-204X2013000500002

Trugilho PF, Lima JT and Mori FA (2003). Canonical correlation of physical and chemical characteristics of the wood of Eucalyptus grandis and Eucalyptus saligna clones. Cerne 9: 66-80.

Trzeciak MB (2012). Formação de sementes de soja: aspectos físicos, fisiológicos e bioquímicos. Tese (Doutorado em Agronomia). Escola Superior de Agricultura "Luiz de Queiroz", Universidade de São Paulo, Piracicaba. Available at[http://www.teses.usp.br/teses/disponiveis/11/11136/tde-26042013-164651/en.php]

USDA (2016). United States Department of Agriculture. Foreign Agricultural Service Circular Series WAP 2-16 World Agricultural Production, February 2016. Available at [http://usda.mannlib.cornell.edu/usda/current/worldagproduction/worldag-production-02-09-2016.pdf]. Accessed March 3, 2016.

Vanzolini S and Carvalho NM (2002). Effects of soybean seed vigor on field plant performance. Rev. Bras. Sementes 24: 33-41. http://dx.doi.org/10.1590/S0101-31222002000100006

Genetics and Molecular Research 16 (2): gmr16029547 